\title{
Routine Promotions: Li Hu and the Dusty Byways of Empire
}

\author{
R. Kent Guy
}

In Imagined Communities, Benedict Anderson writes of the imperial functionary's experience of geography:

He sees before him a summit rather than a centre. He travels up its corniches in a series of looping arcs which, he hopes, will become smaller and tighter as he nears the top. Sent out to township A at rank V, he may return to the capital at rank $\mathrm{W}$; proceed to province $\mathrm{B}$ at rank $\mathrm{X}$; continue to vice-royalty $\mathrm{C}$ at rank $\mathrm{Y}$; and end his pilgrimage in the capital at rank $\mathrm{Z}$. On this journey there is no assured resting-place; every pause is provisional. The last thing the functionary wants is to return home, for he has no home with any intrinsic value. And this: on his upward-spiralling road he encounters as eager fellow-pilgrims his functionary colleagues, from places and families he has scarcely heard of and surely hopes never to have to see. But in experiencing them as travelling-companions, a consciousness of connectedness ('Why are we ... here ... together?') emerges, above all when all share a single language-of-state. ${ }^{1}$

Anderson means here to contrast the experience of the imperial functionary with, on the one hand, the feudal official, who makes one trip to the capital to be invested in office and then returns to his native place; and, on the other hand, with the popular representative, who makes repeated trips to the capital serving the interests of those he represents. Elements of Anderson's picture are of course inappropriate to Chinese officials of the late-imperial era. No Chinese official would ever have publicly admitted that he had no home of any intrinsic value, and not every Chinese official's career ended in the capital. But Anderson's arresting description is nonetheless valuable for the historian of China in so far as it turns our attention to the lessons Chinese officials learned as they journeyed down the dusty byways of empire.

For Anderson's purposes, the looping arcs and corniches are random, but from the point of view of officials making the journeys, they seldom were. Most empires, including late-imperial China, had ladders and hierarchies,

1 Benedict Anderson, Imagined Communities (London, 1983), 55. 
particularly in territorial governance, which functionaries climbed as their careers advanced. These hierarchies were spelled out in broad terms in official documents, like the Collected Statutes of the Qing (Da qing hui dian). But these regulations served more to express parameters than determine careers; the interesting issue is how choices were made within these parameters and what these choices tell us about the goals of the empire. The purpose of this article is to show that the biographies of officials prepared by the State Historiographical Commission, read carefully, provide a telling view of the logic of official careers in China. ${ }^{2}$ There are of course limits to this approach. The interpersonal interactions, gift giving, and social networks so highlighted in existing accounts of literati life, do not appear in the State Historiographical Commission biographies. However, focus on these elements tends to obscure the encompassing structure, legal, official and economic, which actually constrained bureaucratic life.

The career of $\mathrm{Li} \mathrm{Hu}\left(175^{-1785}\right)$ is particularly useful for this reading. His career was not entirely typical nor unique, but significant in its length. It is possible to trace his ascent from the first magistracy he was assigned in 1748 at the age of 33, until he died in his last posting as governor of Guangdong Province in 1785. This account will focus on the first twenty-three years of his career, when he rose from the rank of magistrate to provincial governor, broadly exploring the issue of how an eighteenth-century empire chose its agents. It will argue that the eighteenth-century Qing state favoured officials with general rather than specialised knowledge, despite the existence of regional contexts requiring quite specialised functions. It tolerated associations among officials, particularly when they organised themselves around common tasks rather

2 These biographies were prepared after an official died, according to the following procedure. First an agency of the Qing government memorialised the throne requesting that an official biography be prepared. If the request was approved, the State Historiographical Commission communicated with relevant agencies of the Qing government to assemble career details and the most important state papers of the individual. A draft biography was then written which was reviewed and very carefully edited. These biographies today exist in two collections. In the mid-nineteenth century, Li Huan a junior official in Beijing, methodically copied out the state biographies of the most important officials, and published them in his Guochao qixian leizheng (Xiangyin 1884-19o, hereafter GCJXLZ). In this collection, State Historiography Commission biographies are labeled as 'Guo shi guan ben zhuan', 'Original biographies from the State Historiographical Commission'. Some state biographies were also printed in Qing shi lie zhuan in the twentieth century. Since the State Historiographical Commission was established only in the 1730s, most of its subjects were eighteenth- or nineteenth-century officials. For a discussion of these biographies and how they were produced, see Feng Erkang, Qingdai renwu chuanji shiliao yanjiu (Beijing, 2004). 
than common interests. Finally it will show how the central government used the circulation of officials to solve specific regional problems.

\section{Li Hu and the Road to Fat City}

Tales of high officials who began their careers studying for the examinations by the light of a sputtering candle were as common in late-imperial Chinese literature as such individuals were rare in practice. Indeed the task of rising through the ranks of examination students to join the 'stars in the heavens' must have seemed a daunting one, particularly for someone like $\mathrm{Li} \mathrm{Hu}$, who began with few connections in the official world. Even for those who passed the examinations, mobility was not assured. John Watt has suggested that those whose first appointment was as magistrate inhabited a bounded career stratum with limited opportunities for promotion. ${ }^{3}$ The case of $\mathrm{Li} \mathrm{Hu} \mathrm{dem-}$ onstrates, however, that an ascent to and through the ranks of magistrates could be accomplished. The personnel sections of the Qing code, particularly the post-designation system, outlined the terms under which such an ascent could be made. The post-designation system assigned degrees of difficulty and importance to all the posts in the empire based on the functions its occupants usually performed and accorded provincial officials a larger role in filling posts of greater importance. ${ }^{4}$ Establishing the tasks commonly associated with a post and how they were assessed is crucial to reading the record of transfers that often marked the beginning of an official career.

Li Hu's family were urbanites who resided within the walls of Nanchang, the capital city of Jiangxi province, probably working either in the official establishment or in the pottery industry that dominated the city's economy in the eighteenth century. $\mathrm{Li} \mathrm{Hu}$ was the first member of his family to hold a civil degree, although one Li from Nanchang received his military jinshi in 1720, and served as a second captain in a battalion stationed at Zhangzhou in southern Fujian. Li Hu received the coveted highest jinshi degree in 1739, the fourth year of the Qianlong reign, ranking 172 nd in a class of 328.5

3 John Watt, The District Magistrate in Late Imperial China (New York, 1972), 76.

4 On the history of the post-designation system, see R. Kent Guy, Qing Governors and their Provinces: The Evolution of Territorial Administration in China 1644-1796 (Seattle, 2010), 97-108.

5 Wei Yuanguang, comp., Nanchang xian zhih (Nanchang, 1918, rep. Chengwen, Taibei, 1969), I, 451. The gazetteer does not identify Li Yuan as a relative of Li Hu's, although two out of the eight Lis from Nanchang city who received degrees in the eighteenth and nineteenth 
While the early Qianlong years were a good time for examination takers, they were not a good time for job seekers. Special examinations marking the ascension of the new emperor to the throne, together with the relatively large graduating classes in the regular exams of 1736 and 1739, meant that there were nearly 700 new jinshi produced between 1735 and $1740 .{ }^{6}$ In this large cohort Li's ranking meant that he needed to wait in line for appointment. Connections could have helped - seven graduates with ranks below Li's in the 1739 examination received appointments in the Hanlin Academy in 1740. But Li was left to seek office through routine procedures for the appointment of new jinshi to local office. These provided that the names of five new jinshi in evennumbered months, and four new jinshi in odd-numbered months, be placed in a pool of twenty-three names from which were selected by lot the men who would fill any vacant magistracies. There was some bias in the early eighteenth century for older magistrates so the fact that $\mathrm{Li} \mathrm{Hu}$ was only twenty-four at the time he received his degree probably worked against him. Whatever the factors involved, Li had to wait nine years for his first posting as magistrate of Wucheng county in Shandong in 1748 (fig. 1$)^{7}$

Li Hu probably found his first posting to have been worth the wait. Although Wucheng was counted a magistracy of only middling importance in the Qing personnel system, the advantages of its location compensated for its modest formal status. ${ }^{8}$ Wucheng was situated in north-west Shandong, squarely within the north China economic core. The Grand Canal, which flowed through the centre of the county, brought a regular stream of commerce and official visitors past the county magistrate's office. By the 1750s, as Susan Mann has argued, western Shandong had experienced nearly two hundred years of economic growth, interrupted briefly by the dynastic transition. As a result, by 1750 the Grand Canal trade centres of western Shandong had 'ceased to be primarily exporters of raw material, dependent on southern grain imports and manufactured items', becoming instead 'nodes of a highly differentiated, locally specialised trading system characterised by a mix of agricultural products and

centuries are identified as relatives of $\mathrm{Li} \mathrm{Hu}$. On the pottery industry in Nanchang see Nagel's Encyclopedia Guide to China, Anne L. Destenay trans. (Geneva, 1978), 1110.

6 William Hung, Comp., Chin Shih T'i Ming Pei Lu of the Ch'ing Dynasty (Harvard Sinological Index Series, Supplement \#10 Beijing, 1940, rep. Taipei, 1965), 79-86. On the routine procedures for the appointment of new jinshi to magistracies, see Watt, The District Magistrate, 45-47. Li's age of twenty-four placed him distinctly at the young end of the jinshi class.

7 '(Li Hu) Guo shi huan ben zhuan', in GCJXLZ, 179.24a.

8 This information is drawn from Que zhi quan lan (1904, rpt. Wemhai, Taipei, 1967), I, 346. This was a privately published list providing critical information for each posting in the empire, This guide would have constituted an official's introduction to his new posting. 
handicraft industry.' Wucheng in particular had developed a merchant community that was prosperous enough and sufficiently well organised to have undertaken to pay the commercial tax quota of the county, so that goods could be traded tax-free in the county seat. ${ }^{9}$

Wucheng also offered advantages to a young magistrate without political connections. The county was in the commercial hinterland of the provincial capital of Jinan and well within the political horizons of Shandong provincial governors, who were in the eighteenth century a rather powerful and well-connected lot. The nine officials who governed Shandong during Li Hu's thirteen years of service as magistrate in the province included one Chinese and six Manchu bannermen, most of whom had long records of service at court or in the Manchu military establishment. Only two regular Chinese civil officials served as governor of the province; together they served only seventeen months. Wucheng also bordered on Zhili, which was governed by another powerful group of officials, well known and trusted by the court. Li Hu served at least the standard

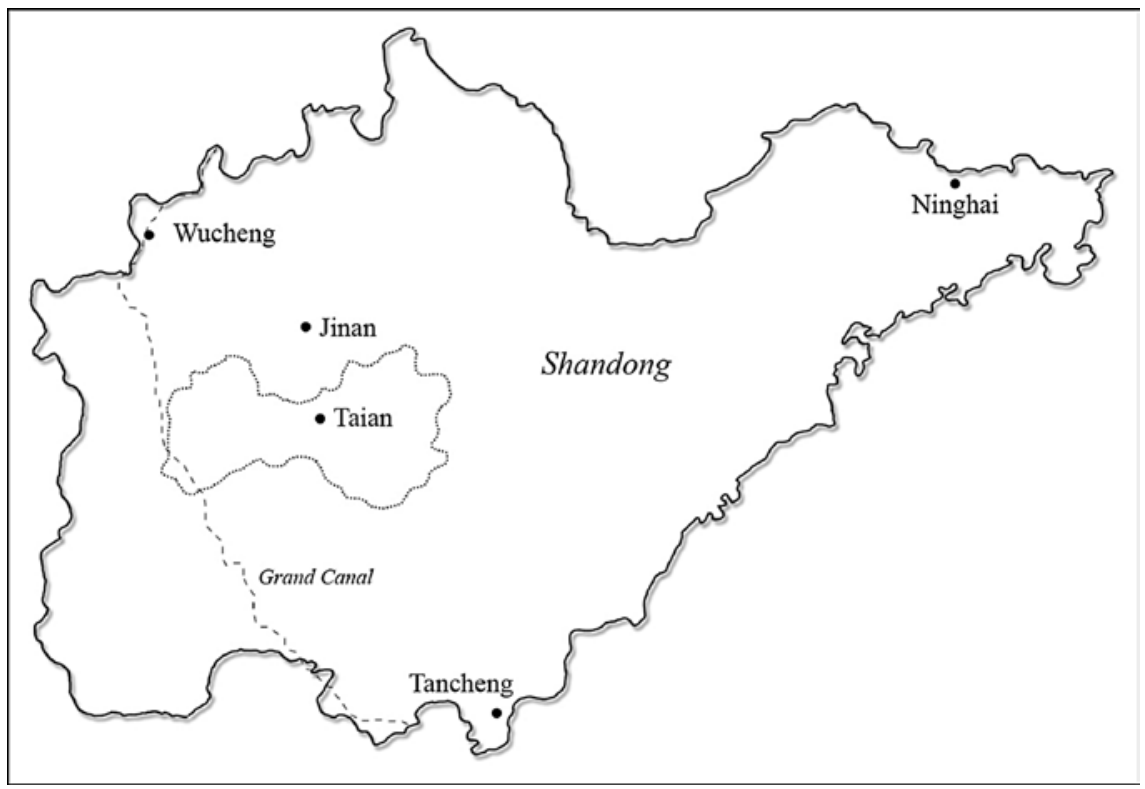

FIGURE 1 Map of Li Hu's posts in Shandong. Adapted from: Tan Qixiang, Zhongguo lishi dituji [The Historical Atlas of China], Vol. 8 (Beijing, 1982), 22-23.

9 Susan Mann, Local Merchants and the Chinese Bureaucracy, 1750-1950 (Stanford, 1987), 53. See also G. William Skinner, 'The Structure of Chinese History', Journal of Asian Studies 44, no. 2 (1985), 271-74. For Wucheng's official status, see Que Zhih Quan Lan, I, 446. 
three-year term in Wucheng and is credited with having successfully organised a subscription campaign to renovate a local temple. ${ }^{10}$

Li Hu's second posting took him to a very different quarter of Shandong province. Tancheng, in the south of the province, was a poor county well outside the economic mainstream, susceptible to floods and famines and near enough to the provincial border to serve as refuge to bandits and fugitives. A magistrate who had served there seventy years before $\mathrm{Li} \mathrm{Hu}$ had written that many of its people 'held their lives to be of no value for the area was so wasted and barren, the common people so poor and had suffered so much that they essentially knew none of the joys of being alive.'1l Tancheng was not only a less desirable place to live than Wucheng, it was in financial terms a less important one. While Wucheng had a tax quota of 23,80o ounces of silver, Tancheng was only required to remit 18,500 ounces of silver. Moreover, there was a difference in the yang-lian, or 'nourishment of virtue' stipend associated with each position; the magistrate of Wucheng received 1400 ounces of silver per year, while the magistrate of Tancheng received 1200 ounces. ${ }^{12}$ As Madeleine Zelin has pointed out, yang-lian should not be conceived of as salary in the western sense; it was meant to cover a wide range of public expenses, including pay for the magistrates' clerks, assistants and runners, other office expenses and even official entertainment. Differences in yang-lian, therefore, reflected not so much the different values of a post to the occupant, as western salaries might, as differences in the assessment of a post's needs and expenses. ${ }^{13}$

It is hard to imagine how $\mathrm{Li} \mathrm{Hu}$ could have welcomed his transfer to this land of ghosts and nightmares, so vividly described by Jonathan Spence in The Death of Woman Wang. And yet within the logic of the Qing personnel system Li probably did welcome his appointment, if not the new challenges it posed. Probably because of its long history of calamity, Tancheng was rated by the Qing government as a 'difficult' post, and an important one. Because of this designation it was one of twenty-six magistracies, out of the ninety-six in the province, which were filled not by the Board of Personnel in Beijing but by

10 On the Shandong governorship see Guy, Qing Governors and Their Provinces, 188-192. Li's achievements as Wucheng magistrate are documented in Nanchang Xian Zhih, II, 948. My impression — and it is only that — is that in counties where there was a strong merchant presence and where the mercantile community contributed to the maintenance of order, the civil official's role was regarded as less difficult and consequently less important.

11 Huang Liu-hung, quoted in Jonathan D. Spence, Death of Woman Wang (New York, 1978), 14.

12 On Tan-cheng's status, see Que zhi quan lan I, 438.

13 Madeleine Zelin, The Magistrate's Tael: Rationalizing Fiscal Reform in Eighteenth Century Ch'ing China (Berkeley, 1985), 116-166, passim. 
the Shandong provincial governor. ${ }^{14}$ In the case of Tancheng, the governor was limited in his selection to individuals who had served as magistrate without incident for at least three years. In this context, Li's appointment in Tancheng meant that he had attracted the attention and earned the confidence of the Shandong governor. Once in Tancheng, Li addressed rather different tasks than he had in Wucheng, proposing the construction of eight new granaries and encouraging peasants to reclaim lands for agriculture that had previously been devoted to animal husbandry. ${ }^{15}$

It was perhaps with relief that $\mathrm{Li} \mathrm{Hu}$ received word of his next posting, in 1755, as magistrate of Ninghai Department, also in Shandong. ${ }^{16}$ This appointment brought $\mathrm{Li}$ his first promotion in rank, from $7 \mathrm{~b}$, the rank of country magistrates, to $5 \mathrm{~B}$, the rank of department magistrates. It also brought him somewhat greater and different responsibilities than he had held previously. While all Qing magistrates were reviewed by provincial governors, county magistrates reported first to prefects, and then to governors. Departments, however, were not incorporated into prefectures, and their magistrates were directly supervised by provincial governors. As G. William Skinner has noted, ordinary departments tended to be somewhat more peripherally located than counties, and this was the case in Ninghai, which was situated on the north-east coast of the Shandong peninsula near Yantai. The department was 375 kilometres away from Jinan and was the easternmost official posting in Shandong. Although the tax quota of the Department and the official salary of its magistrate were equal to those of Wucheng, $\mathrm{Li} \mathrm{Hu}$ was able and required to act more independently than he had ever done before. To be sure, nothing in his previous experience had prepared him for life on a sea coast or the administration of a sea port, much less the delicate task of dealing with the increasing, if illegal, seaborne migration to Manchuria which used Yantai as a point of departure. However, Li Hu had shown himself to be trustworthy, able to handle the demands of Confucian administration in both wealthy counties and poor, and to merit the promotion that went with the Ninghai appointment. ${ }^{17}$

Li served in Ninghai for six years, longer than he had served in any post in his official life; when his next appointment came in 1761 it was probably the most

\footnotetext{
14 On the Shandong governor's prerogative to fill magistracies, see Guy, Qing Governors and their Provinces, 101-102, and 196.

15 On Li's work in Tancheng, see Nanchang Xian Zhih, II, 948.

16 '(Li Hu) Guo shi guan ben zhuan', GCJXLZ 179.24a.

17 On the status of ordinary Departments, see G. William Skinner, 'Cities and the Hierarchy of Local Systems', in G. William Skinner, ed., The City in Late Imperial China (Stanford, 1977), 320-331, passim. On Ninghai's adminstrative status, see Jue Zhih Quan Lan, I, 452.
} 
important of his official career. Li's next post as prefect at Tai'an, Shandong, not only entailed an increase in salary and responsibility and recognition of Li's ability by the central court in Beijing, but took him back to Shandong's agricultural heartland. Li's new post was comprised of seven magistracies and was located directly to the south of Jinan Prefecture in which the provincial capital was located. While tax collection was not Li's direct responsibility, the magistrates under Li had a collective tax quota of 176,710 ounces of silver, and Li's yang-lian salary as prefect was 3000 ounces of silver, more than double what he had been paid in Ninghai. The greater responsibility Li held was also reflected in an increase in rank, from $5^{B}$ to 4 A..$^{18}$

Although the Qing code stipulated that successful department and county magistrates could be promoted to prefect, the occurrence could hardly have been routine. There were in Qing China some 1553 magistracies, including counties, departments and autonomous departments, but there were only 85 prefectures. Above the prefectural level in local administration, there were 92 circuit intendancies, and 18 provincial judgeships. The odds of a magistrate being promoted to prefect were approximately 1 in 18 ; whereas the odds of being promoted into a provincial judgeship from a prefecture were slightly better than one in five. Because of the importance of prefectural positions, the central court much more closely controlled them than the lower-level posts within the local administration. When the post of prefect of Tai'an became vacant, the fact was reported to the emperor who then chose the new appointee from among the officials known to him. Since $\mathrm{Li}$ had never served at the capital, the emperor's knowledge of him was probably not personal, but founded on recommendations of Shandong governors. Nonetheless, the fact the Li's name came up, and that he was ultimately selected for the post at Tai'an must be taken as a sign of his growing stature within Qing bureaucracy. Tai'an was a post to be coveted: after nine years of waiting for office and thirteen years in subordinate and peripheral posts, $\mathrm{Li}$ administered a prefecture containing a magistracy whose name, Fei cheng, could be somewhat facetiously if not inaccurately translated as 'Fat City'.

Li's journey to 'Fat City' was not marked by any signal achievement, but by a steadily accumulating record of competence in positions of increasing responsibility, observed by multiple governors in contexts emphasising tax collection, policing and independent judgment. Historians have tended to see all magistrates as the same, neophytes from the capital with only privately published works of advice and a few legal secretaries to help them out. But as

18 Que Zhih Quan Lan, I, 426. The Qing administrative system had nine ranks, each divided into two subgrades, with $9 \mathrm{~b}$ the lowest rank and 1a the highest. 
Li's career suggests, occupants of different magistracies had varying degrees of experience and different relations with their superiors. Although the knowledge magistrates like Li possessed was general rather than specialised, it was their capacity to apply such knowledge in varying contexts that determined their advancement.

\section{Life in the Fast Lane: The Logic of Competence and the Logic of Connections}

Li Hu's career took a rather different direction after his appointment in Tai'an. First, he served in different geographical venues. While all of his appointments before Tai'an were in Shandong, none of his subsequent appointments were. In Shandong, Li held four positions in fifteen years and increased his rank by two grades. During the ten years following his appointment in Tai'an, Li was appointed to seven posts, rising two more grades and moving rapidly through the middle reaches of provincial administration. Underlying both of these changes was a shift in the logic of Li's appointments. In Shandong, Li's competence apparently attracted the attention and earned the confidence of several provincial governors, who appointed him to posts of gradually increasing responsibility. Beginning in the 1750 s, however, Li's career was shaped by and identified with the commitments of specific group of officials, and their needs dictated his appointments. Li had, in short, acquired a patron.

The first sign of the workings of a patron in Li's career was his transfer in 1763 to Daming, the southernmost prefecture of Zhili, which bordered Shandong province on the east, and Honan on the west (fig. 2). Judging from its tax quota of 341,561 ounces of silver, which was more than twice that of Tai'an, Daming was a wealthier district than Li had served in before. Moreover, it was a district with historical associations, having once served as the seat of the provincial governor of Zhili. But the most significant feature of the appointment, from Li's point of view, was probably that it was one of the prefectures in Zhili for which the governor-general'syamen was allowed to recommend an appointee. ${ }^{19}$ His next appointment, to Baoding prefecture brought him directly into contact

19 Provincial governors were allowed to recommend appointments for magistracies designated as important, or very important. In the case of prefectures, the central court reserved for itself the right to appoint men to important and very important posts, and governors were allowed to recommend appointees to a relatively few less important posts. However, there were a certain number of postings which were, as a result of negotiations between provinces and the state, fixed at the provincial level. 


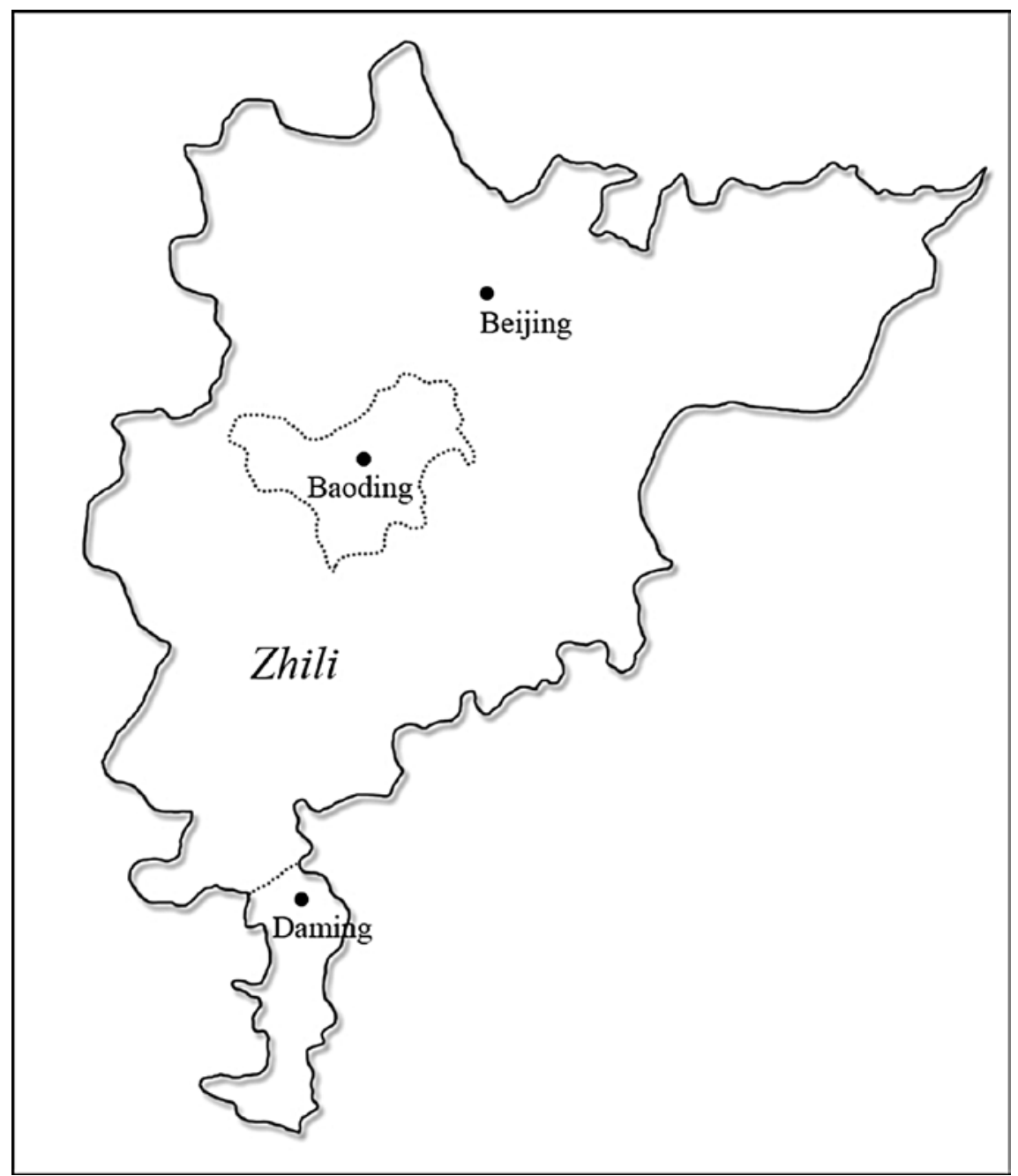

FIGURE 2 Map of Li Hu's posts in Zhili. Adapted from Tan Qixiang, Zhongguo lishi dituji [The Historical Atlas of China], Vol. 8 (Beijing, 1982), 7-8.

with the governor-general, since that prefecture served as his official seat. In 1768, Li was appointed intendant of the Qinghe circuit in northern Zhili, and in 1771, he was promoted to provincial judge for Zhili. ${ }^{20}$

20 Baoding was a 'petition post'. Governors were allowed to petition the emperor requesting that a given official be appointed. This differed slightly from a 'transfer post' like Tancheng in Shandong, in which a governor's recommendation was routinely accepted without the 
As he rose through Zhili administration, $\mathrm{Li} \mathrm{Hu}$ followed the path of senior officials in the province. For over a third of the Qianlong reign, the governor-generalship of Zhili was in the hands of Fang Guancheng and his protégé Zhou Yuanli, who were serving respectively as governor-general and provincial judge when Li Hu arrived in Baoding in 1765 . All three officials held a similar sequence of positions in Zhili administration. Fang Guancheng was first appointed in the province in 1742, as intendant of the Qinghe circuit, and rose to be governor-general in 1749. Zhou Yuanli was appointed prefect of Baoding in the 176os and intendant of the Qinghe circuit from 1764-1768. He was promoted to provincial judge in 1769 and to lieutenant governor in 1770 .

A crucial position in each of these cases may have been the Qinghe circuit intendancy. The role of circuit intendant was a rather unusual one in eighteenth-century China. While most territorial officials had responsibility for the performance of all the functions of government within a territorially defined jurisdiction, circuit intendancies were usually functionally defined, with the intendant responsible for travelling over a wide area and assuring that one matter was performed correctly. In the case of the Qinghe circuit, whose geographical scope consisted of most of the province, the issue was water control. The area of Zhili constituted the northeast extremity of the delta of the Yellow River and as such was crossed by numerous rivers and streams that rose in the Daxing Mountains along the western border of the province and flowed east. $^{21}$ The peril inherent in these rivers was suggested by the alternate name for the Yongding River, Hunhe, or 'River of Chaos'. Modern readers would know this river as the one spanned by Marco Polo Bridge, where the Sino-Japanese War began in 1937. When excessive rain beginning in the spring of 1725 brought flooding to the areas due south of Beijing, the Yongzheng emperor ordered his younger brother Prince Yi to investigate the water conservancy projects of Zhili. The outgrowth of this investigation was the creation of a new circuit intendant in central Zhili, who had the responsibilities of overseeing local administration in the eight magistracies nearest Baoding and supervising the river works in the area. ${ }^{22}$ In addition to maintaining these crucial hydraulic works, the Qinghe intendant and his superiors were responsible for the main-

need for the emperor to approve a petition. On the difference between 'petition' and 'transfer' posts, see Guy, Qing Governors and their Provinces, 101-02.

21 This division of Zhili watercourses follows the account provided by Wu Bangqing in Jifu hedao guanjian, which is reprinted in the same author's Jifu hedao shuili congshu (1824).

22 See Eminent Chinese of the Ch'ing Period (1943; rpt. SMc, Taipei, 1991) 923. Prince Yi's memorials to the throne on the situation in central Zhili are collected in Jifu hedao shuili congshu. 
tenance of the imperial travelling lodges in the precincts around the capital. The Qianlong emperor in particular liked to make frequent trips outside the capital; the most famous of these excursions were, of course, his journeys to the south, but he also made frequent shorter journeys to sites in north China and even used the travelling lodges on his yearly trips to the summer palace at Rehe. Fang and Zhou Yuanli acquired a reputation for maintaining the sites of imperial visits, and greeting the emperor appropriately on his travels, and its seems likely that in the course of these journeys, Li Hu would have met the emperor or those close to him.

Fang Guancheng inhabited a stratum of the Qing bureaucracy in which who one knew was as important as what one knew. ${ }^{23}$ Born into a family tainted in the early eighteenth century by allegations of treason, Fang had not taken the civil service examinations but had served instead as a Chinese amanuensis to a Manchu general and a clerk in the nerve centre of Qing government, the Grand Council. His own rise was clearly dependent on patrons and connections, and once he had achieved high office, he used it to further the careers of younger officials he trusted, Li Hu and Zhou Yuanli (1705-1775). However, Fang was also a very competent official, as Pierre-Etienne Will has shown. Regulations he evolved became the basis for Qing famine relief policies in the eighteenth and nineteenth centuries. The political reputations of Fang, Zhou, and Li rested both on their connections and on their reputations as competent officials. The third quarter of the eighteenth century was a relatively prosperous period in north China, with the regional economy growing and the White Lotus uprisings of the later years of the century still far away. In such 'periods of peace', wrote the editors of Qingshigao in their assessment of Fang and his followers, 'shepherding the people consists of providing for their prosperity, maintaining the irrigation works, and encouraging agricultural production. ${ }^{24}$

\section{Regional Needs and Central Policies: Two Jurisdictions}

The death of Fang Guancheng in September of 1768 was only one of a number of deaths of senior officials, most of whom had served the emperor since he ascended the throne. Initially, the court's reaction to all this change, in Zhili

23 Eminent Chinese of the Ch'ing Period, 133-135, Qing shi gao (1927, rpt. Guofang, Taipei, 1961) 4275-76. See also Pierre-Etienne Will's study of Fang's contribution to Qing famine relief policies, Bureaucracy and Famine in Eighteenth Century China (Standford, 1990), passim, particularly 14-16.

24 Qing shigao 4284. 
as elsewhere, was to turn to senior statesmen whose abilities were known and whose standing was secure. Yang Tingzhang, a hereditary commander of the Chinese Bordered Yellow Banner Army who had served as governor of Zhejiang, governor-general of Min-zhe and Liang-guang, and president of the Board of Punishments, was appointed governor-general of Zhili in 1768. As the moment of crisis passed, however, the central government turned to rising Chinese stars in the provincial bureaucracy. The cohort of officials that had surrounded Fang Guancheng dispersed to positions of leadership throughout the empire. Between 1770 and 1775, thirteen Chinese, many of whom had come up through the ranks of provincial administration, received their first appointments as governor. ${ }^{25}$ As they dispersed, their careers came to be determined more by central than local needs, more by historical contingency than by the logic of local promotions.

In 1771, Li Hu was promoted from the provincial judgeship in Zhili to the lieutenant governorship of Jiangsu. The change of venue was not particularly unusual; most of those who moved up through the ranks of provincial administration were appointed governor in a different region from where they had served as provincial subordinates. But the post represented a mark of confidence in Li Hu. The Jiangsu finance commissionership, with its responsibility for the tax revenue and grain tribute of one of the empire's most productive provinces, was in the eighteenth century a post for officials of experience and proven competence. Li's immediate predecessor in the position, Sazai, also became his superior. A Manchu of the Imperial Household Department, Sazai had spent his life in Jiangsu and was to serve as governor of the province for five years before being promoted to the post of director of the River Conservancy for the southern provinces. A second indication of the importance of the Jiangsu finance commissionership was the character of the officials appointed to it. While it was in theory possible for finance commissioners to have been promoted from the ranks of provincial judges, very few Jiangsu commissioners were. In the twenty years before Li Hu's appointment (1750-1770) only four of fourteen appointees were promoted from the office of provincial judge, and three of these were Jiangsu provincial judges who served in the Jiangsu Finance commissioner's office very briefly before moving on to other appointments. Half of Li Hu's predecessors had served as finance commissioners in other provinces before taking office in Jiangsu, and five of Li Hu's fourteen predecessors were promoted to governorships on the conclusion of their service.

The need for specialised personnel in Jiangsu was probably dictated by the special contributions of the province to the empire. Although a relatively small

25 On this transition see Guy, Qing Governors and Their Provinces, 134-137. 
province in size, Jiangsu was required to remit a tax quota of 2,836,593 ounces of silver annually, the largest tax quota in the Qing empire. In addition, the province also had to provide a major portion of the annual grain tribute, which fed the armies and officials of north China. Governing in Jiangsu thus inevitably entailed the vital but delicate task of extracting revenue from a prosperous, well-established and often recalcitrant local landholding elite who, by virtue of the province's success in the civil service examinations, were often well connected at the capital. It is perhaps not surprising that the task was not left to neophytes or that eighteenth-century Jiangsu governors who had shown themselves capable like Sazai tended to remain in place for a long time. ${ }^{26}$

It was while he was in Jiangsu that Li wrote his first memorial on policy to the Qianlong Emperor. ${ }^{27}$ The proposals Li offered earned the emperor's approval, but perhaps as important, the memorial earned Li the respect of his fellow officials and was reprinted in the privately edited early-nineteenthcentury compendium of administrative writings Huangchao jingshi wenbian (Essays on statecraft in our times). The subject of Li's memorial was a rather vexed issue for late-eighteenth-century officials, the proper role of imperial appointees in the management of community granaries. Community granaries were one of three institutions where grain was stored for emergency relief and other purposes in Qing China, the other two being charitable granaries, privately endowed granaries located for the most part in urban settings, and the 'ever normal granaries' where the tax and tribute grain collected by the state was stored. Community granaries were located in rural communities and funded by private contributions, and in theory they were not subject to state regulation. In the early eighteenth century, however, officials concerned that government stocks of grain were inadequate to meet emergency needs had encouraged private contributions to community granaries, and even used state funds in some cases to purchase grain for community granaries. By the latter

26 On the difficulties of collecting revenue in Jiangnan, see James Polachek, 'Gentry Hegemony: Soochow in the T'ung Chih Restoration', in Frederic Wakeman and Carolyn Grant, eds., Conflict and Control in Late Imperial China (Berkeley, 1985) particularly 217228; Zelin, The Magistrate's Tael, 221-264; Lawrence Kessler, 'Chinese Scholars and the Early Manchu State', Harvard Journal of Asiatic Studies 31 (1971), 179-200.

27 It is the practice in the field of Chinese history to refer to all communications to the emperor as 'memorials'. They were broadly of two sorts, routine (tiben) and secret (zouzhe). Routine memorials could be submitted by any official and were reviewed by the relevant bureaus in Beijing. Secret memorials could be submitted only by officials of the rank of lt. governor or higher, and were read by the emperor or his staff in the Grand Council. When they were first used, secret memorials concerned primarily military matters, but by the 1770 s they were used for many purposes. Li Hu's was a secret memorial. 
third of the eighteenth century the Qing state was having difficulty monitoring the supplies of community granaries, which were often located far from official yamens, and the fairly full community granaries were increasingly vulnerable to requisition by officials whose straightened budgets left them little flexibility in the areas of relief and public works. ${ }^{28}$

In his memorial, $\mathrm{Li} \mathrm{Hu}$ made three proposals to improve the management of community granaries. First he proposed that the rule which required that the private managers of community granaries be changed yearly be revised to allow one manager to serve for up to three years, as long as he served competently. Second, Li proposed that local magistrates be required to check the account books of community granary managers yearly and that magistrates' subordinates be sent into villages after the harvest to compare household registrations with the granary managers' reports of grain disbursed. Third, if such inspection showed corrupt management, Li proposed that local managers be punished severely. ${ }^{29}$ Although the memorial was concerned exclusively with the technical details of granary management, this earliest of Li's preserved official writings served to locate Li in official time and space in interesting ways. Li's writing betrayed an activist optimism about the ability of local officials to monitor community granary management that was more characteristic of the early eighteenth century than its last years. By the later third of the eighteenth century, Qing officials no longer had such an optimistic view. In 1799, the Jiaqing Emperor decided that the problems of official supervision of community granaries outweighed the advantages and decreed that henceforth community granaries would be freed from official supervision. ${ }^{30}$

Perhaps as interesting were the sources and potential audiences of Li's memorial. It was a proposal based on somewhat limited experience of life in Jiangsu: Li was appointed lieutenant governor in the third lunar month of 1770 , and it probably took him some weeks to take up his appointment. Since he signed the memorial with the title 'Acting Governor of Jiangsu' it was written after the tenth lunar month, when Li temporarily held the governor's office while Sazai was summoned to Beijing for official consultations. It could not,

28 See R. Bin Wong, 'Decline and Its Opposition: 1781-1850', in Pierre-Etienne Will and R. Bin Wong, eds., Nourish The People: The State Civilian Granary System in China, 1650-1850 (Ann Arbor, 1991), 86-89. The definitions of the three types of granaries given here are from the same author's 'Introduction' to Part I of this volume.

29 The memorial is summarised in Li's official biography, in GCJXLZ 179.24a; and printed in full in Huangchao jingshi wenbian (1826, n.p.) rpt. Guofang (Taibei, 1964) 1023-24 (40.30a-32a).

$30 \quad$ Wong, 'Decline and Its Opposition: 1781-1850', 86-89. 
however, have been written any later than the twelfth lunar month, when Li was promoted to the governorship of Guizhou. In essence, Li's memorial was based on the experience of one agricultural cycle in Jiangsu. Also, community granaries do not appear to have been particularly important in Jiangsu. In the year in which Li Hu wrote his memorial, almost 200,000 of the 375,000 shi of grain theoretically in Jiangsu granaries was actually in arrears. Peter C. Perdue and R. Bin Wong have argued that Jiangsu was one of six provinces in which, for political and economic reasons, 'little or no grain' was held in rural and community granaries. ${ }^{31}$ Charitable and community granaries were, however, important in Zhili, and particularly so for the officials of Fang Guancheng's circle. Between the time of Fang Guancheng's appointment in 1748 and his death in 1768, the amount of grain stored in charity granaries in Zhili grew from 206,688 shi to 594,328 shi, and Fang himself is credited with having compiled a volume of maps of charity granaries, Jifu yicang $t u$, perhaps to celebrate his accomplishment in this respect. The volume listed a total of 1005 granaries designed to serve 39,687 villages. ${ }^{32}$ At the very least, Li's memorial appears to have been an attempt to apply expertise gained in one jurisdiction to administrative realities in another.

But perhaps, in view of the limited importance of charity granaries in Jiangsu, the memorial had another purpose: to share Li's own views and expertise with the Qing court, in effect to make a contribution more to a national-level discourse about grain administration than to a local one. In so memorialising, $\mathrm{Li} \mathrm{Hu}$ was perhaps advertising his arrival on the eighteenth-century political stage. The right to address secret memorials to the throne and hence command the emperor's attention on an issue one perceived to be significant was limited to officials who held the rank of lieutenant governor or higher. If this hypothesis is correct, one might further speculate that Li was announcing his arrival at senior rank and doing so in a way that called attention to the particular group of officials from which he had emerged. In this sense Li's memorial pointed to a past dominated by the regional concerns of Zhili and a future on the national political stage. $\mathrm{Li} \mathrm{Hu}$ had made his transition.

31 R. Bin Wong and Peter C. Perdue, 'National Patterns of Granary Activity', in Will and Wong, eds., Nourish the People, 305; the figures on Jiangsu grain arrears are from 69 of the same volume.

32 R. Bin Wong, 'The Grand Structure: 1736-1780', in Will and Wong, eds., Nourish the People, 70 ; figures on grain stored in Zhili's granaries are from 313 of the same volume. 
Three events shaped Li Hu's next transfer, to the governorship of Guizhou Province along China's southern border. The first was likely the arrival of $\mathrm{Li}$ Hu's memorial in the capital, and the emperor's subsequent endorsement of the memorial in principle. Second, there was the increasingly troubling corruption of mining and military matters in the south-west; allegations of corruption had ended the terms of three recent governors of Guizhou: Gong Zhaolin (governed 1770) who was executed for his part in south-west corruption and Liang Qing (governed 1768-1769) and Fang Shijun (governed 1764-1767) who were allowed to commit suicide for their parts in corrupt activities. Finally, Governor Sazai had an audience with the emperor, the purpose of his trip to Beijng, during which he would have reviewed the capacities of many of his provincial subordinates, and particularly his lieutenant governor. It was at this audience that Li Hu's new appointment was decided upon; Sazai reported in a memorial in early February, 1771, that he had received an oral edict that $\mathrm{Li} \mathrm{Hu}$ be transferred to Guizhou. ${ }^{33}$

The long-standing concerns of the Guizhou governor, with the mining industry in the western part of the province and the troubled relations of Han immigrants with Miao in south-east Guizhou, were very different from those with which Li Hu had been confronted either in north China or in the lower Yangtze valley. The Qing expansion to the south-west, which culminated in the establishment of a regular administration there in the late 1720s, had been accompanied by the opening of copper, silver, and lead mines, and trouble with the indigenous peoples. Mining operations were particularly complex; precious metals had to be extracted from the earth, collected for transport and then distributed to mints throughout the empire. A large network of miners, transport workers, and middlemen had to be coordinated. As many of the transactions in this process were carried out far from official inspection and the amounts of money were not small, the possibility of corruption was great. It was a single case of corruption in one Guizhou mining county that brought down three of Li Hu's predecessors, and Li Hu arrived in Guiyang, the provincial capital, just in time to mop up the case. ${ }^{34} \mathrm{He}$ also began a process

33 Sazai's memorial acknowledging receipt of Li Hu's appointment is in the Number One Archive, Beijing, in the 04-01-12-0140 category.

34 In this case, Governor Liang Qing accused the Prefect of Wei Ning of having deficits in his treasury. The prefect responded with a long, detailed, and documented list of the instances in which Liang Qing and his predecessors extorted money from him. The case led to the downfall of the prefect but also to that of three governors accused of extortion. 
of research, interviewing local officials and reviewing record books and regulations, which allowed him to produce within three months of his arrival an extremely long and thoughtful report on mining and distribution. ${ }^{35}$ Within a further two weeks, he produced a second lengthy report on provisioning the armies which were necessary to secure the south-west and protect its industry. Li Hu had no experience in either of these areas, but the combination of diligent research and patient sincerity allowed him to produce assessments that the State Historiographical Commission found appropriate to record. ${ }^{36}$

In replacing Gong Zhaolin, whom the court had come to see as a specialist with narrow capacities, ${ }^{37}$ with $\mathrm{Li} \mathrm{Hu}$, the court was opting for a generalised competence over specialised crisis-management in Guizhou. This choice was informed by the perceived short-term needs of the province, but it also served the dynasty's long-term policy goals in the south-west. Recent studies of the region have argued that Qianlong policy in the south-west was one

The documents for this case are published in Qianlong chao cheng ban tanwu dang'an (Beijing, 1994), Vol. 1, 103-208.

The memorial is summarised in Li Hu's biography, '( $\mathrm{Li} \mathrm{Hu}$ ) Guo shi guan ben zhuan', GCJXLZ, 179.24b-25a. The original, lacking the first several pages, is in the Number One Archives, Beijing, document \# 04-01-30-0481-021. A copy of the memorial, made for recordkeeping in Beijing, is in the National Palace Museum Archives, Taipei, Junji chu dang \# 014514.

36 This memorial is summarised in Li's biography, '( $\mathrm{Li} \mathrm{Hu})$ Guo shi guan ben zhuan', GCJXLZ, 179.24b. The original is in the Number One Archives, Beijing, document \# 04-01-35-1279-032.

37 After a career in local administration, Gong had been appointed provincial censor of Hunan in 1767 . He first attracted central attention when he provided crucial information, as Hunan provincial censor, to imperial investigators in a complex case of financial peculation, official collusion and murder in late 1766 . Ultimately, the case led to the cashiering of three Hunan officials and the execution of the former governor of Hunan Li Yinpei. Impressed with Gong's forthrightness, the court rushed him to Guangxi to replace a governor indicted on charges of corruption, then to Hunan, and finally to Guizhou to deal with a Miao uprising. After the moment of crisis in Guizhou had passed, however, the court began to have concerns about Gong's ability to handle the routine demands of civilian administration. Doubts mounted when Guanyinbao, the finance commissioner of the province, reported in an imperial audience that Gong was boastful, rash of speech, and so brusquely dismissive of others' concerns that the people of the province had taken to calling him 'iron lips'. Finally, when the Board of Revenue memorialised indicting Gong for failing to report a change in the arrival date of a shipment of precious metal from the Guizhou mines to the capital, and the Board of Civil Appointments reported that such an offense merited cashiering, the emperor decided that Gong should be relieved of his duties and ordered to report to the capital. See Qing shi gao, 4388-4389. 
of acculturation, the imposition of Confucian norms of society and government on a complex and difficult border region. ${ }^{38}$ One way in which the central government advanced this goal was to send officials with solid credentials acquired in other parts of the empire into Guizhou to serve and bring to the south-west the benefits of established Confucian governance. Two circumstances, however, almost certainly limited the central government's options in Guizhou. First, the province did in fact have special needs which not every official could be expected to understand or address. Moreover, the province's distance from the centres of power and policy made it unattractive to senior governors whose careers had been established elsewhere.

The journey from the classical gardens and whitewashed estates of Suzhou to the mountains of Guiyang was a long one for Li Hu. But it was a journey eighteenth-century Confucian officials had to be prepared to make. The ambitious goals of the Qianlong court of extending regular Confucian governance to the borderlands required that officials accustomed to governing in the heartlands also serve a season in the south-west. But perhaps as important, the nature of Confucian government itself was at stake in the south-west. Founded as it was on principles presumed to be universal, Confucian government had to work everywhere if it was to work anywhere. It was perhaps a mark of the optimistic idealism of eighteenth-century government that it could routinely transfer officials from the central provinces of the empire to its peripheries and assume their successful service there.

But if it was mark of optimism that officials were sent to the south-west, it was an optimism tempered by realistic recognition of regional differences. Jiangsu and Guizhou represented two fairly acute cases of provinces requiring special treatment, and the Qianlong court's policies toward them suggested the pragmatism which the Qing government brought to its rule in China in the eighteenth century. The source of Jiangsu's claim for special treatment lay in its contributions to the financial foundations of empire. As the argument above suggests, the eighteenth-century government was willing to acknowledge a certain legitimacy to this claim, for the revenue of Jiangnan supported the empire as a whole. Guizhou's claim for special treatment, its troubled minorities and inadequately supervised mines, undermined the legitimacy if not the

38 Christine Lombard-Salmon, Un Example d'Acculturation Chinoise (Paris, 1972); John E. Herman, 'National Integration and Regional Hegemony: The Political and Cultural Dynamics of Qing State Expansion, 1650-1750' (Ph.D dissertation, University of Washington, 1993), and William Rowe, 'Education and Empire in Southwest China: Ch'en Hung-mou in Yunnan, 1733-38', in Alexander Woodside and Benjamin A. Elman, eds., Education and Society in Late Imperial China, 16oo-19oo (Berkeley, 1994), 417-457. 
order of the empire as a whole. Where the dynasty tolerated specialisation in Jiangsu, it fought against the compartmentalisation of Guizhou. In both cases, policy was dictated by the needs of state; both provinces were incorporated into the routine personnel system, but to very different ends.

\section{Conclusion}

Aside from highlighting the standards by which $\mathrm{Li} \mathrm{Hu}$ was judged at various points in his career, the criteria of 'successful stewardship', the narrative above has demonstrated the ways in which the routine promotions system of the Qing structured the careers and mental horizons of Qing civil servants. Part I argued that it was possible for magistrates to be promoted to higher office. But to move up in the Qing civil service, one had to move out; hence the promoted magistrate had to have confronted the tasks of government in several, often quite different, environments and measured local needs against central Confucian standards. The evidence of Part II suggested how the promotions system of Qing civil service structured factions within the Qing provincial bureaucracy. The central government required assessments of officials in order to promote them, but assessments had to come out of a regional context. Therefore in a sense the court was dependent on regional factions and could be said, in fact, to have created them, even as it refused to acknowledge their existence in any but the most perfunctory sense. Finally Part III has shown how regional needs were balanced within a national personnel system and highlighted the demands for mobility and loyalty this placed on civil servants required to journey to distant and sometimes disparate jurisdictions. 